\title{
Effects Of Dietary Management Education On Self-Efficacy And Caregiver Practice In Dietary Care Of Family Members With Type 2 DM
}

\author{
Ria Anggraini ${ }^{1}$, Chriswardani Suryawati ${ }^{2}$, Nurullya Rachma ${ }^{3}$ \\ ${ }^{1}$ Magister Keperawatan, Fakultas Kedokteran, UNDIP, Semarang, \\ 2 Departemen Administrasi Kebijakan Kesehatan, Fakultas Kesehatan Masyarakat UNDIP, Semarang \\ ${ }^{3}$ Departemen Keperawatan, Fakultas Kedokteran,UNDIP , Semarang, \\ Email : riaanggraini118@gmail.com
}

\begin{abstract}
Abstrak
Diabetes melitus tipe 2 merupakan salah satu penyakit yang mempunyai prevalensi yang besar di Indonesia dan di dunia yang menjadi masalah kesehatan masyarakat. Menurut World Health Organization [WHO] (2016), dari semua penderita diabetes di seluruh dunia, 90\% diantaranya adalah penderita DM tipe 2. Data Kementerian Kesehatan Republik Indonesia tahun 2014 juga menunjukan bahwa 90\% dari seluruh kasus diabetes adalah DM tipe 2. Caregiver dalam melakukan perawatan pada anggota keluarga dengan DM tipe 2 membutuhkan efikasi diri dan praktik perawatan diet. Peningkatan efikasi diri dan praktik perawatan diet dapat dilakukan dengan memberikan pendidikan manajemen diet. Penelitian ini bertujuan untuk menganalisa pengaruh pendidikan manajemen diet terhadap efikasi diri dan praktik perawatan diet caregiver. Penelitian ini menggunakan desain quasiexperiment dengan pre and posttest control group design. Jumlah responden adalah 44 caregiver yang diambil dengan teknik purposive sampling dengan kriteria inklusi dan eklusi dan dibagi menjadi dua kelompok. Hasil penelitian menunjukan pendidikan manajemen diet mampu meningkatkan efikasi diri dan praktik caregiver dalam perawatan diet anggota keluarga dengan DM tipe 2 ( $p$-value $=0,000$ dan $\alpha=0,05)$. Pendidikan manajemen diet berpengaruh terhadap efikasi diri dan praktik caregiver. Disarankan agar pendidikan manajemen diet dapat digunakan sebagai salah satu upaya peningkatan efikasi diri dan praktik caregiver dalam perawatan diet pasien DM tipe 2.
\end{abstract}

Kata Kunci: Caregiver, efikasi diri, DM tipe 2, pendidikan manajemen diet

Type 2 Diabetes Mellitus (DM) is one of the public health problems with high prevalence both in Indonesia and in the word. According to the World Health Organization (2016), $90 \%$ of all DM cases around the world is of type $2 \mathrm{DM}$. Data from the Indonesian Ministry of Health in 2014 also showed that $90 \%$ of all diabetic cases in Indonesia were of type 2 DM. In caring for the family members with type 2 DM, caregivers require self-efficacy and practice of dietary care. This self-efficacy and care practice can be improved through dietary management education. This study aimed to analyze the effects of type 2 DM dietary management education on self-efficacy and dietary care practice of caregivers. This quantitative study used a pre and posttest quasi-experimental design with a control group. The samples were 44 caregivers recruited using purposive sampling technique and were assigned to two groups based on the inclusion and exclusion criteria. The results showed that dietary management education could improve self-efficacy and caregiver practice in the dietary care of family members with type $2 D M$ ( $p$-value $=0.000$ and $\alpha=0.05)$. This study concluded that type 2 DM dietary management education program gave effects on self-efficacy and caregiver practice. Dietary management education can be used as an 
alternative to improve self-efficacy and caregivers' practice in the dietary care of patients with type 2 DM.

Keywords: Caregiver, self-efficacy, type 2 DM, dietary management education

Article info:

Article submitted on September 14, 2018

Articles revised on October 12, 2018

Articles received on November 16, 2018

DOI: http://dx.doi.org/10.21927/jnki.2018.6(3).211-218

\section{INTRODUCTION}

Diabetes Mellitus (DM) is a chronic disease characterized by the inability of the body to perform the metabolism of carbohydrates, fats, and proteins, and thereby causes an increase in blood sugar levels (1). Diabetes Mellitus, especially type 2 $\mathrm{DM}$ is a major public health problem that becomes a worldwide concern $(2,3)$.

The International Diabetes Federation (IDF) in 2015 stated that Indonesia is ranked seventh out of the ten highest countries with diabetes. Around $87 \%$ to $91 \%$ of diabetic population in the country is of type $2 \mathrm{DM}$. Currently, the number of diabetics in Indonesia is approximately 10 million people with the age of 20 to 79 years old. By 2040, it is estimated that 16.2 million people suffer from DM $(4,6)$. According to the World Health Organization (WHO) in 2016, about $90 \%$ of all DM cases worldwide are of type 2 DM (7). Similarly, data from the Ministry of Health Republic of Indonesia in 2014 also showed that $90 \%$ of all diabetic cases in Indonesia are of type 2 DM (8).

The treatment of type $2 \mathrm{DM}$ requires the participation of the family. It is because health problems in the family are interrelated, and thus if one family member suffers from a disease, the other family members will also be impacted. This is possible because the family is a collection of two or more individuals living in one place and having emotional bonding, as well as social involvement in interrelated roles and tasks. Thus, one of the family tasks is to provide care to the sick family member (9).
In case that a family member is sick, one or two other family members will usually be on duty to function as the caregivers[9]. However, there is a possibility that the treatment given by these caregivers is of a low quality as they may have low self-efficacy which can affect the quality of treatment they provide. A study by Wu et al (2007) mentioned that increasing self-efficacy towards disease management is an effective way to improve the disease control such as the adherence that is useful for self-care behaviors (10).

Self-efficacy is an individual belief of predicting their ability to perform tasks to achieve certain outcomes well. Self-efficacy can lead an individual to be able to assess whether their have the power to produce something that he/ she wants. Self-efficacy greatly affects one's behavior $(11,13)$.

$\mathrm{Hu}$ and Arao stated that self-efficacy had been recognized as a major factor affecting self-care behaviors for the management of chronic diseases $(13,15)$. A study by Kershaw Halic stated both patients and caregivers affect the mental and physical health of each other. Patients and caregivers who have high selfefficacy tend to have better mental health (16).

In addition to self-efficacy, caregivers should also have an ability to do dietary care for the family members who are sick. Nagelkerk, Halic, reported that the most commonly found barrier in caregivers is the knowledge about dietary plans (17-19). A study by Nurrohmad et al 
also showed that the level of family's knowledge before receiving DM health education was mostly low (55.6\%) (20). Furthermore, Wang et al reported that nutritional education is effective to enhance the knowledge and nutrition practice of people with diabetes (20-22). This relevant information is used in the diabetic education programs to improve the practice of self-care of the caregivers (10). In general, this study aimed to analyze the effects of dietary management education on self-efficacy and dietary care practice of the caregivers.

\section{MATERIALS AND METHODS}

This study used a pre and posttest quasiexperimental design with a control group and was conducted on 10 to 27 July 2017. The population was 145 caregivers living in the working area of a public health center in Blitar. The samples were 44 caregivers recruited using purposive sampling and were assigned to the treatment group $(n=22)$ and control group $(n=22)$. The inclusion criteria were the caregivers of patients with type 2 DM, aged 19 to 59 years old $(23,24)$, able to communicate verbally, and able to read and write. Meanwhile, the exclusion criteria were the caregivers who had physical, mental or cognitive disabilities that might interfere with the study. The homogeneity of subjects' characteristics in the treatment group and control group was tested using the chi-square test. The result showed a $p$-value of $>\alpha(0.05)$, indicating there was no significant difference in each variable in the treatment group and control group.

The dietary management education through lectures and discussions as well as booklets was given to the subjects in the treatment group for two weeks; each lasted for 120 minutes including demonstration. The subjects were given the treatment systematically from package 1 to package 2. In contrast, the control group only received self-management booklets about diet in dealing with the danger of type $2 \mathrm{DM}$ without any dietary education.

The data were collected using questionnaires of self-efficacy and caregiver practice in the dietary care of type $2 \mathrm{DM}$ which had been tested for their validity. The Pearson's product moment correlation test of the questionnaires showed r-count >r-table (0.361), indicating that all questionnaires were valid. The test also showed a Cronbach's alpha of 0.826 for self-efficacy and 0.704 for caregiver practice indicating both questionnaires were reliable. The collected data were analyzed using the Wilcoxon test and Mann-Whitney test.

\section{RESULTS AND DISCUSSION \\ Characteristics of Subjects}

Table 1. Characteristic of Subjects

\begin{tabular}{llcc}
\hline \multirow{2}{*}{ Variables } & \multicolumn{2}{c}{$\mathbf{n}=\mathbf{4 4}$} \\
\cline { 3 - 4 } Age & 18-40 years & $\mathbf{n}$ & $\mathbf{\%}$ \\
\hline \multirow{2}{*}{ Sex } & 41-60 years & 29 & 34 \\
& Male & 23 & 52.3 \\
& Female & 21 & 47.7 \\
\hline \multirow{3}{*}{ Education } & Uneducated & 3 & 6.8 \\
& Elementary & 16 & 36.4 \\
& Junior High & 14 & 31.8 \\
\multirow{4}{*}{ Employment } & Senior High & 11 & 25 \\
& Higher education & 0 & 0 \\
\hline Exposure to type 2 & Farmer & 11 & 25 \\
DM information & Labor & 7 & 16 \\
& Private employee & 13 & 29.5 \\
\multirow{4}{*}{ Source of information } & Housewife & 13 & 29.5 \\
\hline & No & 41 & 93.2 \\
& Health worker & 3 & 6.8 \\
\hline & Internet & 5 & 73 \\
& Did not know & 4 & 9 \\
\hline
\end{tabular}

Source: Primary data

Table 1 shows that the majority of subjects $(66 \%)$ were aged 41 to 60 years old, males $(52,3 \%)$, and hold elementary education (36.4\%). Furthermore, most subjects worked as private employees (29.5\%) and had exposure to type 2 DM information (93.2\%) from the health workers (73\%). 
Table 2. Distribution of Self-efficacy and Care Practice in Intervention Group and Control Group Before and After the Treatment $(n=44)$

\begin{tabular}{lcccc}
\hline \multicolumn{1}{c}{ Variable } & \multicolumn{2}{c}{ Intervention Group } & \multicolumn{2}{c}{ Control Group } \\
\hline \multicolumn{1}{c}{ Self-efficacy } & Pre & Post & Pre & Post \\
\hline Good & $\mathrm{n}(\%)$ & $\mathrm{n}(\%)$ & $\mathrm{n}(\%)$ & $\mathrm{n}(\%)$ \\
Adequate & $5(22.73)$ & $18(81.8)$ & $5(22.7)$ & $5(22.7)$ \\
Inadequate & $12(54.54)$ & $4(18.2)$ & $13(59.1)$ & $11(50)$ \\
\hline Care Practice & $5(22.73)$ & - & $4(18.2)$ & $6(27.3)$ \\
\hline Good & $\mathrm{n}(\%)$ & $\mathrm{n}(\%)$ & $\mathrm{n}(\%)$ & $\mathrm{n}(\%)$ \\
Adequate & $4(18.2)$ & $18(81.8)$ & $5(22.7)$ & $5(22.7)$ \\
Inadequate & $13(59.1)$ & $4(18.2)$ & $13(59.1)$ & $11(50)$ \\
\hline$\Sigma$ & $522.7)$ & - & $4(18.2)$ & $6(27.3)$ \\
\hline
\end{tabular}

Source: Primary data, 2017

Table 3. Mean Difference of Self-efficacy in Intervention Group and Control Group (N1, N2 = 44)

\begin{tabular}{lccccccc}
\hline \multicolumn{7}{c}{ Score of Self-efficacy } \\
\hline \multirow{2}{*}{ Measurement Intervention } & \multicolumn{2}{c}{ Control } \\
\cline { 2 - 8 } & Mean & SD & Min-Max & Mean & SD & Min-Max & p-value \\
\hline Before & 30,00 & 5,354 & $21-40$ & 32,50 & 3,143 & $28-38$ & ${ }^{*} 0.28$ \\
After & 38,00 & 3,367 & $31-45$ & 31,27 & 3,367 & $28-38$ & ${ }^{*} 0.000$ \\
\hline
\end{tabular}

* Mann-Whitney test

Self-Efficacy and Caregiver Practice in Intervention and Control Groups

The self-efficacy and care practice of family caregiver in the intervention group and control group before and after the implementation of dietary management education program is presented in Table 2.

Table 2 shows that of 22 subjects in the intervention group, only $5(22.73 \%)$ had a good level of self-efficacy. After given dietary management education, almost all subjects as many as $18(81.8 \%)$ reached a good level of self-efficacy. In the control group, before the intervention group received dietary management education, four subjects $(18.2 \%)$ had an inadequate level of self-efficacy, and after the intervention group received dietary management education, the number of subjects having an inadequate level of self-efficacy increased to $6(27.3 \%)$. As for the care practice, before the intervention group received dietary management education, four subjects (18.2) had a good level of care practice; meanwhile, after the implementation of dietary management education, the number increased to $18(81.8 \%)$. In the control group, before the treatment was given to the intervention group, four subjects (18.2) were identified to have an inadequate level of self-efficacy, and after the intervention group received the treatment, the subjects with an inadequate level of self-efficacy increased to $6(27.3 \%)$. These results indicated that dietary management education increased the level of self-efficacy in subjects in the intervention higher than that in the control group.

\section{Results of Mean Difference of Self-efficacy Before and After the Treatment in the Intervention and Control Group}

Table 3 shows that in the intervention group, the mean value of self-efficacy of the subjects before the provision of dietary management education was 30.00 , whereas, after the intervention, the mean value increased to 38.00 with $p$-value $=0.000$ and 
$\alpha=0.05$. The $p$-value was $<\alpha$, indicating there was a mean difference in the self-efficacy before and after the intervention. Thus, dietary management education gave an effect on self-efficacy of the caregivers in caring for the family members with type 2 DM.

\section{Mean Difference of Care Practice Before and After the Treatment in Intervention and Control Groups}

Table 4 shows that in the intervention group, the mean value of family practice before the provision of dietary management education was 22.73, whereas after the treatment, the mean value increased to 26.95 with $p$-value $=0.000$ and $\alpha=0.05$, in which $p$-value $<\alpha$, meaning that there was a difference in the mean value before and after the provision of the treatment. Hence, the dietary management education of type $2 \mathrm{DM}$ gave effects on caregiver practice in caring for family members with type $2 \mathrm{DM}$.

The result of the study in Table 3 shows that the mean value of self-efficacy improvement was 38.00 with a $p$-value of 0.000 . This illustrates that the caregivers who received dietary management education had better self-efficacy than that of caregivers receiving no treatment. The improvement of self-efficacy in this study was supported by Rondonuwu who examined the effects of health education on physical exercise self-management on self-efficacy in patients with coronary artery disease. It was evident that the subjects in the intervention group had higher selfefficacy after the provision of health education treatment [25].
The result of the study in Table 4 shows increased care practice with a mean value of 26.95 with $p$-value $=0.000$. This finding is in line with a study by Sari et al. (2016) about foot care behaviors which reported that education program could improve the foot care behaviors of the subjects [26]. The present finding is also supported by Wang et al. who reported that nutrition education was effective to improve the nutrition practice of diabetics (21). The results of this study indicated that there were significant differences in self-efficacy and dietary care practice in the diet treatment of Type 2 DM between the intervention group and the control group after the treatment. Caregivers who received dietary management education had better self-efficacy and better practice in performing dietary care than those who received no such treatment.

\section{DISCUSSION}

The findings in this study indicated that self-efficacy and dietary care practice were highly increased in the subjects in the intervention group. The mean value of self-efficacy increased from 30 to 38 while the mean value of care practice increased from 22.73 to 26.95 . Increased selfefficacy and dietary care practice indicated changes that the subjects make in dealing with diabetes. Unless the program is given, the caregivers may have no confidence in themselves to make some behavioral changes. They may also lack skills in the dietary care of type 2 diabetes.

Table 4. Mean Difference in Care Practice between the Intervention and Control group (N1, N2, = 44)

\begin{tabular}{lccccccc}
\hline \multicolumn{7}{c}{ Care Practice } \\
\hline \multirow{2}{*}{ Measurement Intervention } & \multicolumn{1}{c}{ Control } \\
\cline { 2 - 8 } & Mean & SD & Min - max & Mean & SD & Min - max & p-value \\
\hline Before & 22.73 & 2.746 & $17-28$ & 23.55 & 2.110 & $20-28$ & ${ }^{*} 0.161$ \\
After & 26.95 & 2.572 & $20-32$ & 22.48 & 2.085 & $22-28$ & ${ }^{*} 0.000$ \\
\hline
\end{tabular}

* Mann Whitney test 
The finding of this study is also congruent with a study conducted by Unsal and Kasikci, which investigated the effect of education on self-efficacy in arthritis patients. The study reported that after the provision of education, self-efficacy of patients in the intervention group had a significant increase compared to that of the control group (18).

This study combined lectures and discussions as the treatment, and these methods can play an important role to improve a person's cognition. This is reinforced by Herawati's study which suggested the use of combined methods of lecture and discussion to educate people (27).

The type 2 DM dietary management education in this study is a program package that functions to change the attitudes and behaviors of a person which are related to the cognitive, affective and psychomotor aspects. The program was carried out systematically started from the preparation of materials and media, use of lectures, discussions, demonstrations, and redemonstrations, as well as provision of booklets that can be used by the caregivers at any time after the program is completed.

The use of educational media in the form of dietary management booklet in this study is referring to various literature. The selection of this medium is also based on a study by Atika which suggested that education through the provision of treatment booklets is effective to help improve the patient compliance (28).

In this study, the self-efficacy and care practice of dietary management among caregivers in the intervention group after given the treatment showed a p-value of 0.000 and $\alpha$ of 0.05 . The $p$-value was $<\alpha$ meaning there were different mean values before and after the implementation of dietary management education. In contrast, the self-efficacy and care practice of caregivers in the control group showed a p-value of 0.28 and 0.161 , respectively. Thus, it could be concluded that caregivers who received dietary management education of type 2 DM had better self-efficacy and practice in the dietary care of family members compared with those caregivers who did not receive education of the same type.

\section{CONCLUSION}

There were significant differences in selfefficacy and caregiver practice of dietary care to the family members with type 2 diabetes between the intervention group and control group after the provision of dietary management education. Thus, it was evident that type $2 \mathrm{DM}$ management education gave effects on the caregivers' selfefficacy and practice of dietary care.

Based on the findings, it is recommended that community nurses improve their roles in public health care, especially in families with type 2 DM by the provision of dietary management education. Further studies could examine another variable that may affect the caregivers' practice and behaviors in the treatment of type $2 \mathrm{DM}$, such as dietary education through motivational interviewing that supports self-management program and leads to better caring behavioral changes.

\section{REFERENCES}

(1) J. M. Black and J. H. Hawks, MedicalSurgical Nursing. Clinical Management for Positive Outcomes (6th), Sixth. Saunders: Elsevier, 2009. [cited 2016 November 9].

(2) S. Wild, G. Roglic, A. Green, R. Sicree, and H. King, "Global Prevalence of Diabetes : Estimates for Year 2000 and Projections for 2030.," Diabetes Care, vol. 27, pp. 10471053, 2004. [cited 2016 November 9].

(3) A. M. Aman, H. Rasyid, S. Bakri, and I. J. Patellongi, "The Association Between Parents History of Type 2 Diabetes with Metabolic Syndrome Component and Insulin Resistance in Non-Diabetic Young Adult Male," Acta Med. Indones. J. Intern. Med., vol. 50, no. 4, pp. 309-313, 2018. 
(4) D. R. Whiting, L. Guariguata, C. Weil, and J. Shaw, "IDF Diabetes Atlas : Global estimates of the prevalence of diabetes for 2011 and 2030," Diabetes Res. Clin. Pract., vol. 94, no. 3, pp. 311-321, 2011. [cited 2016 November 10].

(5) N. H. Cho et al., International Diabetes Federation., 7Th ed. Karakas: IDF Diabetes Atlas, 2015.

(6) N. H. Cho et al., "IDF Diabetes Atlas : Global Estimates of Diabetes Prevalence for 2017 and Projections for 2045," Diabetes Res. Clin. Pract., vol. 138, pp. 271-281, 2018.

(7) World Health Organization, Global Report on Diabetes. France: World Health Organization, 2016.

(8) Kementerian Kesehatan RI, Infodatin Diabetes. Jakarta: Kementerian Kesehatan RI, 2014.

(9) Friedman, M. M, Bowden, V. R, Jones, and E. G, Buku Ajar Keperawatan Keluarga: Riset, teori dan praktik, 5th ed. Jakarta: EGC, 2017.

(10)S. Wu, M. Courtney, H. Edward, J. McDowell, L. Shortridge-Baggett, and P. Chang, "SelfEfficacy, Outcome Expectation and SelfCare Behavior in People with Type Diabetes in Taiwan," J. Clin. Nurs., vol. 16, no. 7, p. 250, 2007. [cited 2016 November 10].

(11)A. Bandura, Self efficacy Encyclopedia of Human Behaviour, Indonesia. New York: Academic Press, 1994. [cited 2016 November 11].

(12)A. Bandura, "Self-Efficacy," vol. 4, no. 1994, pp. 71-81, 1998. [cited 2016 November 11].

(13)I. M. Rustika, "Efikasi Diri : Tinjauan Teori Albert Bandura," Bul. Psikol., vol. 20, no. 1, pp. 18-25, 2012. [cited 2016 November 12].

(14)H. Hu, G. Li, and T. Arao, "Validation of a Chinese Version of the Self-Efficacy for Managing Chronic Disease 6-Item Scale in
Patients with Hypertension in Primary Care," ISRN Public Health, vol. 2013, pp. 1-7, 2013. [cited 2016 November 15]

(15) H. Hu, G. Li, and T. Arao, "Validation of a Chinese Version of the Self-Efficacy for Managing Chronic Disease 6-Item Scale in Patients with Hypertension in Primary Care Validation of a Chinese Version of the Self-Efficacy for Managing Chronic Disease 6-Item Scale in Patients with Hy," ISRN Public Health, No. November, 2015.

(16)T. Kershaw, K. R. Ellis, H. Yoon, A. Schafenacker, M. Katapodi, and L. Northouse, "The Interdependence of Advanced Cancer Patients ' and Their Family Caregivers ' Mental Health, Physical Health, and SelfEfficacy over Time," J. Soc. Behav. Med., vol. 49, pp. 901-911, 2015.

(17)J. Nagelkerk, K. Reick, and L. Meengs, "Perceived Barriers and Effective Strategies to Diabetes Self-Management," J. Adv. Nurs., pp. 151-158, 2006. [cited 2016 November 20].

(18)A. Ünsal and M. K. Kaşıkçı, "Effect of Education on Perceived Self-Efficacy for Individuals with Arthritis," vol. 3, no. 1, pp. 3-11, 2010. [cited 2016 December 5].

(19)L. Laranjo et al., "Facilitators , barriers and expectations in the self- management of type 2 diabetes - a qualitative study from Portugal," Eur. J. Gen. Pract. ISSN, vol. 4788, 2015.

(20)E. Nurrohmad, T. Prabowo, and Suwarno, "Pengaruh Pendidikan Kesehatan tentang Diet DM Terhadap Peningkatan Pengetahuan Keluarga Penderita DM di Kelurahan Banyuraden Kecamatan Gamping," Media IImu Kesehat., vol. 4, no. 1, pp. 62-68, 2015.

(21)H. Wang, Z. Song, Y. Ba, L. Zhu, and Y. Wen, "Nutritional and Eating Education Improves Knowledge and Practice of Patients with Type 2 Diabetes Concerning Dietary Intake 
and Blood Glucose Control in an Outlying City of China," Public Health Nutr., vol. 17, no. 10, pp. 2351-2358, 2013. [cited 2016 December 10].

(22)S.-F. V. Wu, M.-C. Lee, S.-Y. Liang, Y.-Y. Lu, T.-J. Wang, and H.-H. Tung, "Effectiveness of a Self-Efficacy Program for Persons with Diabetes : A Randomized Controlled Trial," Nurs. Heal. Sci. (2011), vol. 13, pp. 335-343, 2018.

(23)Undang-Undang RI, “Undang-Undang Republik Indonesia tentang Perlindungan Anak," No. 23, 2002. [cited 2016 December 10].

(24)Undang-Undang RI, "Undang-Undang Republik Indonesia Tentang Lansia," No. 13, 1998. [cited 2016 December 10].

(25)R. H. S. Rondonuwu, "Pengaruh Intervensi Edukasi Kesehatan tentang Manajemen Diri Latihan Fisik Terhadap Self Efficacy Pasien Coronary Aartery Disease di RS Manado Sulawesi Utara," Univesitas Indonesia, 2012. [cited 2016 December 13].
(26)C. W. M. Sari, H. Haroen, and Nursiswati, "Pengaruh Program Edukasi Perawatan Kaki Berbasis Keluarga terhadap Perilaku Perawatan Kaki pada Pasien Diabetes Melitus Tipe 2 Effectiveness of Family Based Foot Care Education Program towards Foot Care Behavior of Type 2 Diabetes Mellitus Patients," vol. 4, p. 305-314. [cited 2016 December 23].

(27) H. H. P, Masruroh, and Y. O. Triwijayanti, "Pengaruh Pendidikan Pengetahuan Remaja Putri tentang Kebersihan Aalat Genetalia di SMA Negeri 1 Ungaran," J. Keperawatan Matern., vol. 2, no. 2, pp. 90-97, 2014.

(28)A. W. Puspitasari, "Analisis Efektivitas Pemberian Booklet Obat Trehadap Tingkat Kepatuhan Ditinjau dari Kadar Hemoglobin Terglikasi (HbA1C) dan Morisky Medication Adherence Scale (MMAS)-8 pada Pasien Diabetes Mellitus Tipe 2 di Puskesmas Bakti Jaya Kota Depok," Universitas indonesia, 2012. [cited 2016 December 7]. 